\title{
An Empirical Discourse Analysis on Correlations between Exchange Rate and Exports
}

\author{
Kittisak Jermsittiparsert \\ Rangsit University, Pathumthani, Thailand \\ Chayongkan Pamornmast \\ Mahanakorn University of Technology, Bangkok, Thailand \\ Thanaporn Sriyakul \\ Mahanakorn University of Technology, Bangkok, Thailand
}

\begin{abstract}
This study's objective focuses on empirically analysing the discourse on the correlations between exchange rate and exports, which has been reproduced constantly and extensively in Thai society by authorities from academic circles and public and private sectors. Hence, this study analyses the time series data of exchange rate and exports by means of advanced statistical methodologies, the regression analysis and Johansen's cointegration test. The regression analysis finds that the exchange rate is negatively correlated to the exports, but Johansen's cointegration test results contrariwise that there is no cointegrating relationship in-between. Therefore, such claim is not an error made in good faith but another example of domineering discourses enabling the elites to take advantages by disguising them as knowledge and truths, over which the other members in the society dare not to doubt nor dispute.
\end{abstract}

Keywords: Empirical Discourse Analysis, Exchange Rate, Exports

\section{Introduction}

\section{On "Discourse" and "Discourse Analysis"}

"Watakarma" is a terminology in social sciences and humanities that Professor Somkiat Wanthana of the Faculty of Social Sciences, Kasetsart University, translated from "discourse" into Thai according to the conception scattered among the works of Michel Foucault, an important poststructuralist French philosopher, almost three decades ago (Wongsurawat, 2010: 3).

In the same manner as Foucault, who had ascribed an implication to "discourse" on top of the meaning people perceived in everyday life, that is, verbal communication, speech or conversation (Heywood, 2000: 87),

Corresponding author: Kittisak Jermsittiparsert, Ph.D. (Candidate), lecturer, Department of Political Science, College of Government and Public Governance, Rangsit University; academic committee, The Political Science Association of Kasetsart University; research fields: comparative politics and government, democracy, empirical discourse analysis, environmental politics, history of political thought, international relations, local administration, political economy, politics in cultural space, public policy, social research. E-mail: kittisak.j@rsu.ac.th.

Chayongkan Pamornmast, Ph.D., head, Department of Banking and Finance, Faculty of Business Administration, Mahanakorn University of Technology; research fields: banking, econometric, empirical discourse analysis, finance, political economy.

Thanaporn Sriyakul, Ph.D. (Candidate), lecturer, Department of Management, Faculty of Business Administration, Mahanakorn University of Technology; president, The Political Science Association of Kasetsart University; research fields: empirical discourse analysis, labour relation, management, political economy, Thai political history. 
Wantana also gave "discourse" a meaning similar to the original word in English and integrated an implication beyond just the combination of the words "speech" (in Thai, “wata”) and "action” (in Thai, "karma”) in addition (Jermsittiparsert, 2010: 187).

It was more than a decade passed until the understandings on "social text" and "social reality", which were constructed and maintained by language (Alvesson \& Karreman, 2000: 1126), have finally been compiled in a serious manner and published extensively among Thai academic circles through the writings and expatiations by Professor Chairat Charoensinolarn (2006: 19-20) of the Faculty of Political Science, Thammasart University, as the system and practise of establishing/producing identities and meanings for every entity in the society surrounding us, whether it is knowledge, truth, power, or our own identity, as well as maintaining the things we have created and socially accepted in general, until it finally turned into a "dominant discourse".

Using the "power" that has been refined/purified to "knowledge/expertise" through the traditional rules and practises of the "experts/authorities" into a form of "academic discourse" on certain topics looks as though it is natural, neutral, universal, objective and harmless to any person (Charoensinolarn, 2008: 421-422), being a label adhered to the complex circumstances of strategic competition for dominance in society (Charoensinolarn, 2006: 25-26) to force/make any perspective which is not necessarily true to become a "knowledge" or the "truth".

In regards to critical inquiry, "discourse" has become a very popular subject, expanding over various academic fields within a short period after Foucault's passing (Vighi \& Feldner, 2007: 141), and appeared in textbooks and science-oriented forums under a variety of different meanings (Jorgensen \& Phillips, 2002: 1), but it was often lack of an established definition. Only presumptions were made, similarly to "discourse analysis" (Cheek, 2004: 1141) which was essentially a study and research on the procedure, methodology, sequence, and details of any establishment of identities and meanings for various entities in the society surrounding us in the form of discourse, along with the practices and impacts of the discourse on certain topics in the terms of relationship (Charoensinolarn, 2006: 27-28).

From the development of linguistics in its early age through anthropology in the 1960s and psychology in the early 1970s (van Dijk, 2007) to interdisciplinary in the modern days (Schiffrin, Tannen \& Hamilton, 2001: 1), over 40 approaches of discourse analysis are all associated with studying and analysing the use of language (Sarangi, 2009 cited in Crichton, 2010: 13) with qualitative methodology (Hodge, Kuper \& Reeves, 2008), which widely brought about questions regarding the negligence of scientific reasonableness (Freshwater, Cahill, Walsh \& Muncey, 2010: 502), in order to explain the language structure, the function of the text, and identifying the relationship between the text and social context in particular (Stillar, 1998: 14), rather than validating the information (Charoensinolarn, 2006: 29) with empirical data, statistics or quantitative methodology, which is criticised as the (flawed) method of scientific social sciences or logical positivism (Charoensinolarn, 2008: 432).

\section{Discourse on the Relationship between "Exchange Rate" and "Exports"}

Modern literature reviews still have not yet reached a conclusive presumption regarding the characters, timing, location, or context in the emergence of the discourse on the relationship between "exchange rate" and "exports." It is only known that this matter is closely associated with the economic theory which indicates that the competitiveness between domestic and foreign operators is strictly related to price, which 
in turn is determined by the exchange rate (Schembri, 1989; Piana, 2001). With this principle, it is assumed that whenever the currency devalues, export would increase while import decreases (Patchimnan, 2011: 217).

The abovementioned assumption has consequently been adhered to and reproduced in the academic circles, public and private sectors of Thailand; e.g. Kriengsak Chareonwongsak (n.d.), Professor of Economics; Krirkkrai Jirapaet (Manager Online, 2006, 18 December), Former Minister of Commerce; Kosit Punpiemrat (Bangkok Biz News, 2006, 19 December), Former Deputy Prime Minister and Minister of Industry; Office of Industrial Economics (2007); Pongsak Assakul (Thai Post, 2006, 12 June), Chairman of Thai Chamber of Commerce; and Payungsak Chatsuttipol (Bangkok Biz News, 2010, 14 October), President of the Federation of Thai Industries. Thus, such has led to an implementation of financial policy by the government to provide assistance, which has brought about questions, similar to those raised by Ammar Siamwalla (Prachachat, 2010, 21 October), Honorary Academician of Thailand Development Research Institute, regarding whether such scheme is appropriate, who gets the benefits, and what this is ultimately for.

\section{Objective of the Research}

This "Empirical Discourse Analysis on Correlations between Exchange Rate and Exports” was conducted to analyse the relationship between the exchange rate and exports, as it would further uncover whether the discourse the authorities reproduced repetitively is a logical and reliable truth or is merely an erratic, inaccurate, and doubtful perspective full of endeavours to coerce a high status, or to put it differently, trying to make such viewpoint become a knowledge as well as the truth.

\section{Methodology}

\section{Data and Variables}

The researchers selected time series data, which have been consecutively and systematically collected, publicly available, reliable, and generally referred by authorities and agencies, covering a period of 172 months from August 1997 to November 2011, on the following variables:

(1) Exchange Rate (ER2), specifically the reference exchange rate of Thai Baht (THB) to United States Dollar (USD) as per the average exchange rates of commercial banks in Bangkok, from the Bank of Thailand (2001, 2012), herein defined as the independent variable of exports

(2) Exports (EXPORT2), specifically the exports of goods according to balance of payments statistics from the Bank of Thailand (2011), herein defined as a dependent variable of the exchange rate.

\section{Data Analysis}

Mainstream discourse analyses specifically focus on the structure, strategy, and process (van Dijk, n.d.) of the (re)productions of discourses, spanning across all types of social activities (Gadavanij, 2006: 31), which even Foucault (1994: xiv) has admitted that they are complicated and cumbersome, not easy to explain to clarity, plus the definitions of technical terminologies to be far from understandable, from those in dictionaries or from those used on a daily basis by the people require an expertise in encryption more than academic language as in the old paradigm, which opposed with a claim that it is a form of language of power that emerged as a knowledge and truth (Charoensinolarn, 2008: 422).

Particularly when the purpose of an analysis shift from the matter of objectivity, or whether something is 
true or false (Heywood, 2000: 88), to abstraction, that is, the rules which govern the texts by degrading human value as a principal to a mere "skeleton" duty bound to follow/reinforce/reproduce such rules only (Charoensinolarn, 2006: 29), virtually all of the researches based on the assumptions of denying the existence of objective reality are left with purely constructed facts in the end (Moreland, 2005: 79), that is, it is an amusing game but all empty, caught in the turmoil of using subjectivity to predict such rules that even oneself could not verify whether it is true. Moreover, the concept of "verification" was denounced/condemned against by presuming that it was just a narrow-minded essence of logical positivism (Charoensinolarn, 2008: 11-12), instead of borrowing such concept to render explanations more efficient and guide the masses towards enlightenment and awareness of the logical inconsistency/crevice of discourses, as well as the lack of the quality of being radical (Charoensinolarn, 2006: 8).

Hence, the Empirical Discourse Analysis or EDA has been developed in order to requite Foucault (1980: 53-54) in the same manner as he did to Friedrich Nietzsche, a German existentialist philosopher, that is, revising his approach by borrowing the principle of empiricism to perform a "falsification" on the core of the texts constructed from variables, brought together with "statistical language" and reproduced constantly and extensively until there is not any question among members of the society from the very beginning, by employing the same data set, logic, and methodology as its production, that is, quantitative methodologies, regression analysis to identify any relationships amongst variables and Johansen's cointegration test (Johansen, 1988, 1991) to double-check such relationships whether they are cointegrated or not, if any, via built-in computer software, instead of simply discussing them as a discourse or discursivity on the subject in point (Charoensinolarn, 2006: 3).

\section{Results and Discussion}

\section{Exchange Rate}

The time series data analysis on the exchange rate shows that it begins at 32.48 THB to USD in August 1997 and ends at 30.96 THB to USD in November 2011. On a monthly basis, the exchange rate fluctuates over time, but in overall, it has a tendency to decrease, with a peak of 53.81 THB to USD in January 1998 and the lowest at 29.88 THB to USD in August 2011.

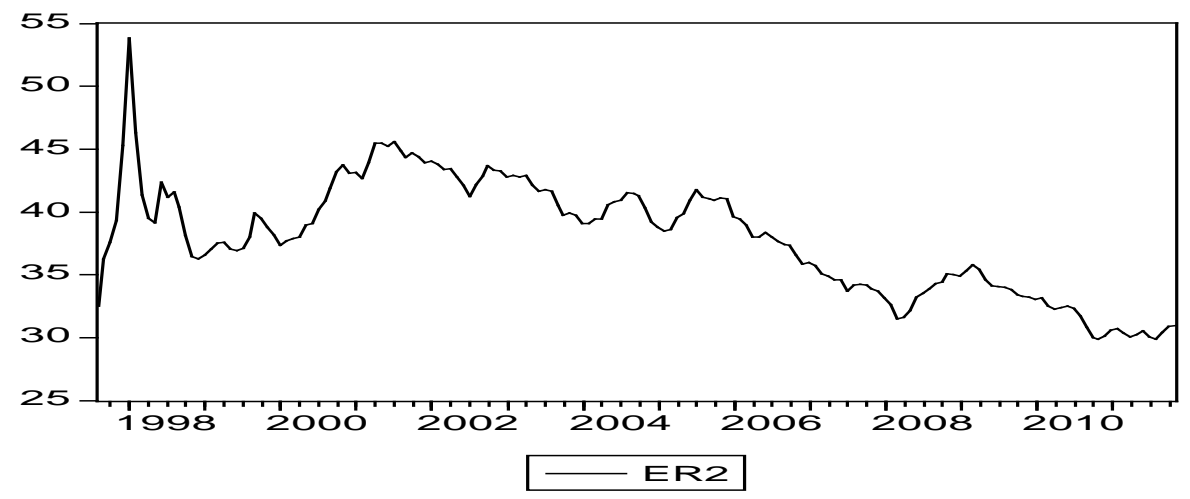

Figure 1. Exchange Rate.

Through regression analysis, Table 1 indicates that time has a positive relationship with the exchange rate at statistical significance of .01 . For every month that progresses, the exchange rate would shift in the opposite direction by 0.07 THB to USD (revaluation). 
EXCHANGE RATE AND EXPORTS

Table 1

Regression Analysis of Exchange Rate and Time

\begin{tabular}{lllll}
\hline Variable & Coefficient & Std. Error & t-Statistic & Prob. \\
\hline $\mathrm{C}$ & 43.67124 & 1.198020 & 36.45285 & 0.0000 \\
$\mathrm{~T}$ & -0.065582 & 0.010185 & -6.439168 & 0.0000 \\
\hline R-squared & 0.526053 & Prob(F-statistic) & & 0.000000 \\
Newey-West HAC Standard Errors \& Covariance (lag truncation=4) & & \\
\hline
\end{tabular}

\section{Exports}

The time series data analysis on exports show that they begin at 4,954.96 million USD in August 1997 and ends at 15,496.37 million USD in November 2011. On a monthly basis, exports fluctuates over time, but in overall, it has a tendency to increase, with the lowest at 3,979.00 million USD in January 1999 and the peak at 21,258.72 million USD in September 2011.

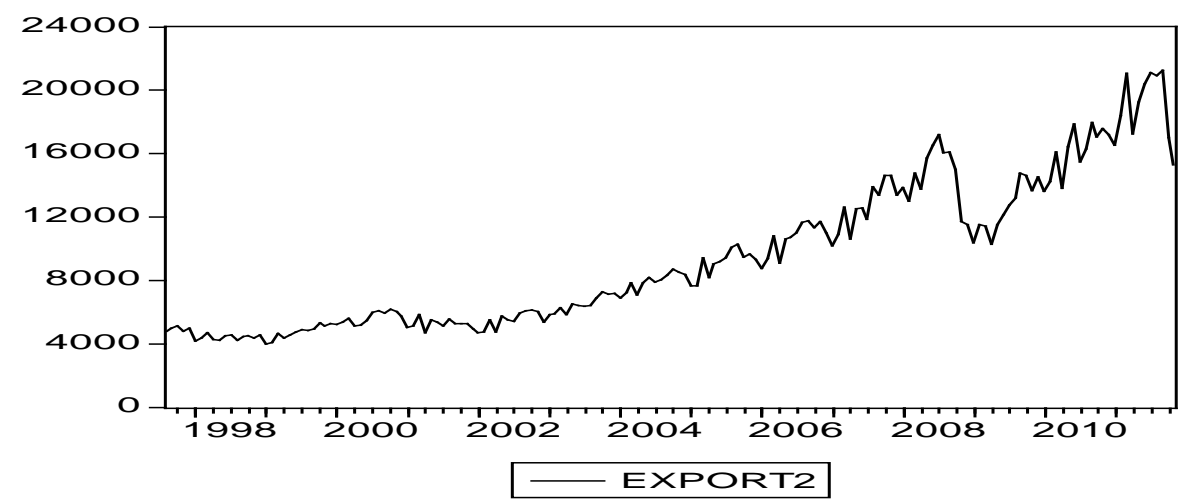

Figure 2. Exports.

Through regression analysis, Table 2 indicates that time has a positive relationship with the exports at statistical significance of 0.01 . For every month that progresses, the exports would shift in the same direction by 86.81 million USD.

Table 2

Regression Analysis of Exports and Time

\begin{tabular}{lcccc}
\hline Variable & Coefficient & Std. Error & t-Statistic & Prob. \\
\hline $\mathrm{C}$ & 1916.948 & 522.2072 & 3.670857 & 0.0003 \\
$\mathrm{~T}$ & 86.80657 & 6.098984 & 14.23296 & 0.0000 \\
\hline R-squared & 0.868461 & Prob(F-statistic) & & 0.000000 \\
Newey-West HAC Standard Errors \& Covariance (lag truncation=4) & & \\
\hline
\end{tabular}

\section{Correlation between the Exchange Rate and Exports}

Initially, the regression analysis has found that the exchange rate has a negative relationship with exports at statistical significance of .01. For each USD that changes in the exchange rate, the exports would shift in the opposite direction by 844.83 million USD. Moreover, the variable of exchange rate can explain $67.27 \%$ of the variation in the exports.

It is concluded at this stage that the discourse on the relationship between the exchange rate and the exports created by the authorities, claiming that THB revaluation would affect price competitiveness and cause 
the exports to decline, is not exactly true. The regression analysis has shown contrariwise that the two variables may have an actual relationship with each other, but in the opposite direction, contrary to such claim or dominant discourse aforementioned.

Table 3

Regression Analysis of Exchange Rate and Exports

\begin{tabular}{lcccc}
\hline Variable & Coefficient & Std. Error & t-Statistic & Prob. \\
\hline C & 41527.95 & 3271.500 & 12.69386 & 0.0000 \\
ER2 & -844.8314 & 82.40431 & -10.25227 & 0.0000 \\
\hline R-squared & 0.672552 & Prob(F-statistic) & 0.000000 & \\
Newey-West HAC Standard Errors \& Covariance (lag truncation=4) & & \\
\hline
\end{tabular}

Nonetheless, the relationship identified up this point, resulted from the intentional utilisation of non-stationary series data in the regression analysis, may just be spurious (Box \& Jenkins, 1976), and thus requires a double check by means of Johansen's cointegration test.

\section{Cointegration Test between the Exchange Rate and Exports}

Through Johansen's cointegration test, it is found that the exchange rate and exports have no cointegrating relationship at statistical significance of .05 . In other words, the relationship identified in the regression analysis is not only a negative relationship between the pair but also a spurious one.

Table 4

Johansen's Cointegration Test on Exchange Rate and Exports

\begin{tabular}{|c|c|c|c|c|}
\hline Hypothesized & & Trace & 5 Percent & 1 Percent \\
\hline No. of CE(s) & Eigenvalue & Statistic & Critical Value & Critical Value \\
\hline None & 0.058586 & 10.54733 & 15.41 & 20.04 \\
\hline At most 1 & 0.002781 & 0.465157 & 3.76 & 6.65 \\
\hline
\end{tabular}

\section{Conclusion and Recommendation}

\section{Conclusion}

In conclusion, the advanced quantitative methodologies so far have empirically shown that the exchange rate is unrelated to the exports.

However, by using the same data set, logic, and methodology as the construction and linkage of the perspective or the discourse on the exchange rate to the country's export competitiveness, under such claim regarding the price advantages in comparison to the competitors in direct correlation, it has not only revealed the issues of superficiality and lack of empirical evidence of the academicians but also the lack of verification of the authorities, as well as the private sector's lies for its own good.

Under the basis of the structuralist philosophers, which states that "every man speaks with purpose" (Chaika, 2008: 150), it might not be an error made in good faith, but another example of the endeavours to establish and instil a belief on the legitimacy of authorities (Weber, 1977: 325) through language, as such is a powerful and efficient tool, including the (re)productions of discourses to domineer, take economic advantages, and exploit the people of different social classes, all of which are the roots of Thailand's significant and 


\section{EXCHANGE RATE AND EXPORTS}

persistent structural problems, through the abuse of power of authorities to conceal/mask their own perspectives as knowledge and the truths which other members dare not to question nor dispute.

\section{Recommendation}

Although the outcome of the "Empirical Discourse Analysis" may not be of interest to discourse analysers in the current paradigm, the application of this new type of approach could fill the voids in criticisms and empirically reveal the logical inconsistency and crevice of the discourse through "falsification" on the fundamental hypotheses, which is the apparent source of critical inquiry on the texts that have been (repeatedly) produced by the authorities until they become a norm, often overlooked and accepted by the society without any questions nor verification, totally different from the vague process that inclines people to question whether such might be the approach that solely rely on presumptions as previously was.

The application of such methodology as a tool for monitoring and preventing any (re)production of similar discourse would not only raise hopes that the mass public would be able to advance towards enlightenment and awareness further and easier, but also foster streams of criticisms, which are an essential condition to further development of this approach.

\section{References}

Alvesson, M. \& Karreman, D. (2000). Varieties of Discourse: On the Study of Organizations through Discourse Analysis. Human Relations. 53, 1125-1149.

Bank of Thailand .(2001) .Rates of Exchange of Commercial Banks in Bangkok Metropolis (1996-2001).

Bank of Thailand .(2011) .Exports Classified by Product Group (US\$).

Bank of Thailand. (2012).Rates of Exchange of Commercial Banks in Bangkok Metropolis (2002-present).

Bangkok Biz News. (2006, December 19). BOT Ordered Commercial Banks to Reserve Other Currencies 30\%. Retrieved September 11, 2011 from www.bangkokbiznews.com/2006/12/19/news_2237071 5.php?news_id=22370715.

Bangkok Biz News. (2010, October 14). FTI Indicated Strong Thai Currencies Caused Export Units Lost One Hundred Billion THB. Retrieved September 11, 2011 from bit.ly/cysUGK.

Box, G. and Jenkins, G. (1976). Time Series Analysis: Forecasting and Control. San Francisco: Holden-Day.

Chaika, E. (2008). Language: The Social Mirror. (4 ${ }^{\text {th }}$ ed.). Massachusetts: Heinle.

Charoensinolarn, C. (2006). Development Discourse: Power, Knowledge, Truth, Identity and Otherness (4 ${ }^{\text {th }}$ ed.). Bangkok: Wipasa.

Charoensinolarn, C. (2008). Language and politics/the political. Bangkok: Thammasat University.

Chareonwongsak, K. (n.d.). Strong Bath Currency: Problem and Solutions for Thai Exporters. Retrieved September 11, 2011 from www.kriengsak.com/node/296.

Cheek, J. (2004). At the Margins? Discourse Analysis and Qualitative Research. Qualitative Health Research. 14 (8). $1140-1150$.

Crichton, J. (2010). The Discourse of Commercialization: A Multi-Perspectived Analysis. Hampshire: Palgrave Macmillan.

Foucault, M. (1980). Power/Knowledge: Selected Interviews and other Writings 1972-1977. New York: Pantheon Book.

Foucault, M. (1994). The Order of Things: An Archaeology of the Human Sciences. New York: Vintages Book.

Freshwater, D., Cahill, J., Walsh, E. \& Muncey, T. (2010). Qualitative Research as Evidence: Criteria for Rigour and Relevance. Journal of Research in Nursing. 15 (6), 497-508.

Gadavanij, S .(2006). Discourse Studies for Social Research: Theoretical Framework for Empirical Research. In K. Hongladarom and C. Iamanon (eds), Look at Society Through Discourse (pp. 23-48). Bangkok: Chulalongkorn University.

Hodge, B., Kuper, A. \& Reeves, S. (2008). Qualitative Research: Discourse Analysis. British Medical Journal. (337), $570-572$. Jermsittiparsert, K. (2010). Watako (vit) [Review of the book Watako (vit), by K. Wongsurawat]. Journal of Social Sciences and Humanities, 36 (1), 186-192.

Johansen, S. (1988). Statistical Analysis of Cointegration Vectors. Journal of Economic Dynamics and Control, 12, $231-254$. Johansen, S. (1991). Cointegration and Hypothesis Testing of Cointegration Vectors in Gaussian Vector Autoregressive Models. Econometrica. 59 (6). 1551-1580.

Jorgensen, M. and Phillips, L. 2002. Discourse Analysis as Theory and Method. London: Sage. 
Manager Online. (2006, 18 December). “Krirkkrai” Worried about Strong Thai Baht Leading to Miss Export’s Target. Retrieved September 11, 2011 from www.manager.co.th/Business/ViewNews.asp x?NewsID=9490000154651.

Moreland, J. (2005). Truth, Contemporary Philosophy, and the Postmodern Turn. Journal of the Evangelical Theological Society, 48 (1), 77-88.

Office of Industrial Economics. (2009) .Does Exchange Rate Really Affect Exporting?. Retrieved September 11, 2011 from 119.63.88.198/Hot\%20Issue/2550/6.doc.

Patchimnan, A. (2011). Concept and Theories in Political Economy. Bangkok: Pappim.

Piana, V. (2001). Exchange Rate. Retrieved February 14, 2012 from September 11, 2011 www.economics webinstitute.org/glossary/exchrate.htm.

Prachachat. (2010, 21 October). 'Strong Thai Baht' Exposed the Weakness of Industry, any Business Win/Lose... It's Time for Transformation!!. Retrieved September 11, 2011 from net/view_news.php?newsid=02edi01211053\&sectionid=0212\&day=2010-10-21.

Schembri, L. (1989). Export Price and Exchange Rate: An Industry Approach. in R. Feenstra (ed.). Trade Policies for International Competitiveness (pp. 185-216). London: University of Chicago Press.

Schiffrin, D., Tannen, D. \& Hamilton, H. (eds.). (2001). The Handbook of Discourse Analysis. Massachusetts: Blackwell.

Stillar, G. (1998). Analyzing Everyday Texts: Discourse, Rhetoric, and Social Perspectives. California: Sage.

Thai Post. (2006, 12 June). TCC Pushed BOT Control Thai Baht for Exporters. Retrieved September 11, 2011 from www.thaipost.net/news/120606/6114.

van Dijk, T. (n.d.). What Do We Mean by 'Discourse Analysis'?. Retrieved September 11, 2011 from www. discourses.org/journals/das/whatisdiscourseanalysis/index.html.

van Dijk, T. (ed.). (2007). Discourse Studies. 5 vols. London: Sage.

van Leeuwen, T. (2008). Discourse and Practice: New Tools for Critical Discourse Analysis. Oxford: Oxford University Press. Weber, M. (1977). The Theory of Social and Economic Organization. New York: Free

Wongsurawat, K. (2010). Watako (vit). Bangkok: Aksornkaosuay. 